\title{
Tsunami hazard assessment of Guadeloupe Island (F.W.I.) related to a megathrust rupture on the Lesser Antilles subduction interface
}

\author{
J. Roger, B. Dudon, and N. Zahibo \\ Laboratoire de Recherche en Géosciences et Energies, Département de Physique, Université des Antilles et de la Guyane, \\ Guadeloupe, France
}

Correspondence to: J. Roger (jeanrog@ hotmail.fr)

Received: 29 March 2012 - Published in Nat. Hazards Earth Syst. Sci. Discuss.: Revised: 18 January 2013 - Accepted: 31 January 2013 - Published: 13 May 2013

\begin{abstract}
The French Caribbean Archipelago of Guadeloupe is located over the Lesser Antilles active subduction zone, where a handful of earthquakes have reached magnitudes of $\mathrm{Mw}=7.0$ (moment magnitude) and more. According to available catalogs, these earthquakes have been able to trigger devastating tsunamis, either directly by the shake or indirectly by induced landslides. The Guadeloupe Archipelago is known to have suffered from several violent earthquakes, including the $1843 \mathrm{Mw} \sim 8.5$ megathrust event. In this study, we discuss the potential impact of a tsunami generation scenario of a $\mathrm{Mw}=8.5$ rupture at the subduction interface using numerical modeling and high resolution bathymetric data within the framework of tsunami hazard assessment for Guadeloupe. Despite the fact that the mystery remains unresolved concerning the lack of historical tsunami data for the 1843 event, modeling results show that the tsunami impact is not uniformly distributed in the whole archipelago and could show important maximum wave heights. This is easily explained by the bathymetry and the presence of several islands around the main island leading to resonance phenomena, and because of the existence of a fringing coral reef partially surrounding Guadeloupe Island and its satellites. We then discuss the role of source parameters, the arrival times and the protective role of fringing coral reefs surrounding the islands, using tsunami modeling applied on two Guadeloupian touristic coastal places: Sainte-Anne and Saint-François.
\end{abstract}

\section{Introduction}

The eastern boundary of the Caribbean region is characterized by a moderate to high seismicity rate, which allows the accommodation of a $2 \mathrm{~cm} \mathrm{yr}^{-1}$ average convergence between the North Atlantic and Caribbean plates (DeMets et al., 2007). According to the available tsunami catalogs, the whole Caribbean Basin and, particularly, the Lesser Antilles islands have been impacted by a number of tsunamis over the past five centuries (since their discovery). Most of the historical data concerning tsunamis in the Caribbean have been collected by O'Loughlin and Lander (2003). Of course, the reported accounts of wave arrival after an earthquake occurrence, a volcanic eruption or a landslide are more or less detailed and reliable and could always be discussed (Blanc, 2011). Nevertheless, some reports are sufficient to highlight the tsunami threat potential for the Lesser Antilles islands, and particularly for Guadeloupe, where it is now well known that several tsunamis have been able to reach this island (Nikolkina et al., 2010), as well as the other French overseas territories of Martinique, Saint-Martin and SaintBarthelemy. Among these events are the devastating 1755 Lisbon transoceanic tsunami (Roger et al., 2010a,b; Zahibo et al., 2011) and, more regionally, the 1867 Virgin Islands tsunami (Zahibo et al., 2003). Local tsunamis could also have had severe consequences in these islands, as the $<1 \mathrm{~m}$ tsunami triggered by the 2004 Les Saintes $\mathrm{Mw}=6.3$ earthquake affecting the southeastern coasts of Guadeloupe (Le Friant et al., 2008), or the Montserrat pyroclastic flows generating 1-2 $\mathrm{m}$ high tsunamis propagating towards northeastern Guadeloupe in 1997, 2003 and 2006 (Pelinovsky et al., 2004; Trofimovs et al., 2011). Curiously, Guadeloupe was severely damaged by the 8 February 1843 subduction earthquake with a seismic moment magnitude ( $\mathrm{Mw}$ ) of 8.0-8.5, but without being struck by a catastrophic tsunami, according to coeval reports (Feuillet et al., 2011). 


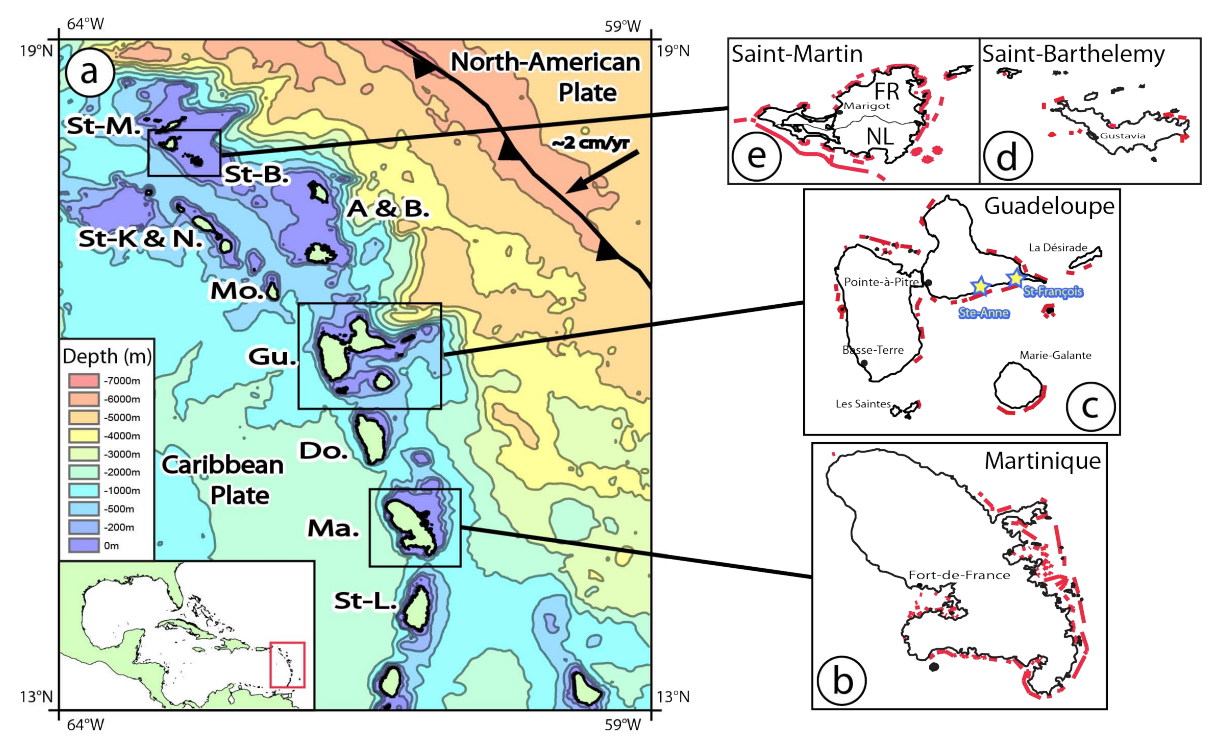

Fig. 1. (a) Location of the French Islands within the Lesser Antilles Arc; Ma.: Martinique; Gu.: Guadeloupe; St-M.: Saint-Martin; St-B.: Saint-Barthelemy; an approximate convergence rate of $\sim 2 \mathrm{~cm} \mathrm{yr}^{-1}$ from DeMets et al. (2007) is indicated as well as the subduction trench between the North American and Caribbean tectonic plates; inset locates the Lesser Antilles Arc in the Caribbean region with a red rectangle. (b), (c), (d), (e) Repartition of the fringing coral reefs (red lines) surrounding the French Caribbean Islands. Saint-François and Sainte-Anne (Guadeloupe) are indicated with yellow and blue stars (c).

Because of a serious increase of coastal population in the last decades mainly due to the touristic potential of its sandy beaches and year round sunny weather, tsunami hazards must be clearly assessed for the Guadeloupe Archipelago.

It is important to notice that this island is partially surrounded by fringing coral reefs (Smith et al., 1997; Feuillet et al., 2002) as well as the other French territories as shown on Fig. 1b-e. They seem to act as efficient natural barriers partially protecting the coasts from wind-wave and cyclonic swell impacts as reported by Clark (1991) and Frihy et al. (2004). Several recent studies show that they also play a predominant role in case of tsunami arrival (Kunkel et al., 2006; Fernando et al., 2008; Liu and Ghidaoui, 2009; Baba et al., 2008; Gelfenbaum et al., 2011). Unfortunately, these reefs are highly threatened by human activities, a threat also re-enforced by storms (Wilkinson, 1999; Bouchon et al., 2008 a,b) as in $75 \%$ of the world's coral reefs, as reported by Burke et al. (2011). In Guadeloupe, the width of the fringing coral reef is approximately $250-300 \mathrm{~m}$ and gap lengths are about 100-200 m (Roger et al., 2013).

In this paper we will discuss tsunami hazard threat for the Guadeloupe Archipelago using numerical modeling of a 1843-like megathrust scenario and sparse destructive Caribbean tsunamis as reference events (such as the 1867 Virgin Islands tsunami). Numerical modeling will also serve to determine, briefly, the fringing coral reefs' capacity of protection against tsunami waves in Guadeloupe Island, focusing on the touristic coastal towns of St François and Ste Anne (Fig. 2) with the help of high resolution digital elevation models (DEM).

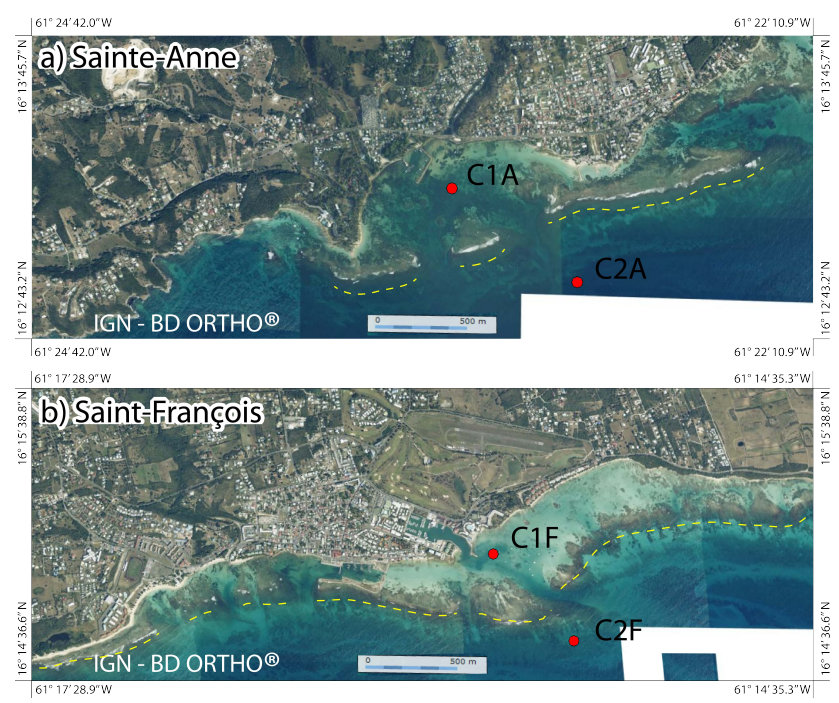

Fig. 2. Aerial view (from IGN-BD ORTHO project, extracted from http://www.geoportail.fr and re-projected in geographical coordinates in WGS84 geodetic system) of Sainte-Anne (a) and SaintFrançois (b) highlighting their coral fringing reefs with yellow dashed line. These towns are located on the inset of Guadeloupe (Fig. 1c). Red circles symbolize synthetic tide gage locations. 


\section{Tsunami modeling}

\subsection{ComMIT}

Preliminary modeling has been realized using ComMIT (Community Model Interface of Tsunami) software from NOAA (National Oceanic and Atmospheric Administration) (Titov et al., 2011). It is an easy to use tool for tsunami inundation modeling using MOST (Method Of Splitting Tsunami; Titov and Synolakis, 1995; Titov and Gonzalez, 1997). Tsunami propagation calculation is based on a numerical dispersion scheme and the nonlinear shallow-water equations in spherical coordinates. The initial deformation needed to compute tsunami propagation is obtained through an analytical numerical model of a rectangular fault plane rupture in an elastic half-space (Gusiakov, 1978; Okada, 1985). The sea-floor deformation is transmitted without loss to an incompressible fluid above.

ComMIT is initialized using source scenarios of the NOAA tsunami pre-computed propagation database. This pre-computed database contains information about tsunami propagation in the open ocean from a multitude of potential sources. Each patch source of dimension $100 \mathrm{~km} \times 50 \mathrm{~km}$ is located on potential tsunamigenic fault zones. It is a good tool for obtaining results quickly, as well as an idea of what could happen in our concerned region.

In our case, the patches have been selected using the source location and rupture parameters determined in agreement with the available bibliography (Bernard and Lambert, 1988) and able to accommodate a $\mathrm{Mw}=8.5$ earthquake (Feuillet et al., 2011). Our source is composed of 9 patches and is shown in Fig. 3. It shows a quite good similarity with the rupture area indicated by Feuillet et al. (2011), enough for preliminary modelings.

Modeling has been done over three imbricated bathymetric grids $\mathrm{A}, \mathrm{B}$, and $\mathrm{C}$ with respectively increasing resolutions of circa $1000 \mathrm{~m}$ (coarse grid over the northern Lesser Antilles Arc), $200 \mathrm{~m}$ (medium grid over Guadeloupe Archipelago) and $40 \mathrm{~m}$ (fine grid over Sainte-Anne and Saint-François). These grids have been prepared using a set of multibeam data from the SHOM (Hydrographic and Oceanographic Service of the French Navy) combined with ETOPO 1 Global Relief Model data set (http://ngdc.noaa.gov/mgg/global/global. $\mathrm{html}$ ), georeferenced and digitized nautical chart of Guadeloupe Archipelago and focus on the town of Saint-François (SHOM, 1994, 2008) coupled with on-site measurements of Saint-François harbor structures (piers, wharfs and marina docks height), and aerial imagery from IGN-BD ORTHO ${ }^{\circledR}$ (extracted on http://www.geoportail.fr) and SRTM 3" (Shuttle Radar Topography Mission) (http://www2.jpl.nasa.gov/ $\mathrm{srtm} /$ ) for inundation calculation (resolution $\approx 90 \mathrm{~m}$ ). Altitude 0 is set to the hydrographic zero, i.e., the sea level value for lowest tide; there is no significant consequence in the Caribbean as the maximum tide amplitude in the Lesser Antilles does not reach $1 \mathrm{~m}$. The different grids are delineated

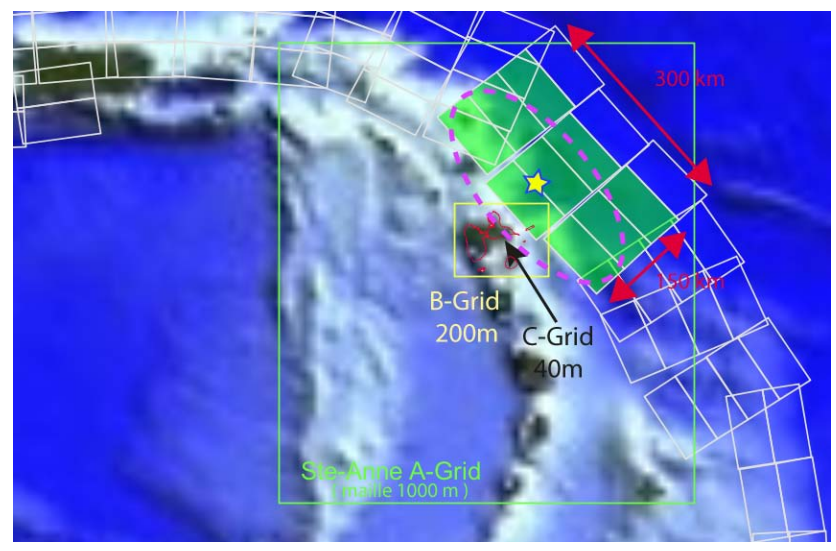

Fig. 3. Area of the 1843 rupture zone and possible epicenter location (yellow star) as proposed by Feuillet et al. (2011) within the northern Lesser Antilles (pink dashed line). The green rectangles represent the available pre-defined patches of ComMIT matching the proposed rupture zone. The geographical extents of grids A (northern Lesser Antilles grid), B (Guadeloupe Archipelago grid) and C (Sainte-Anne or Saint-François grids) introduced in ComMIT are highlighted with empty rectangles.

in Fig. 3. The regular grids, necessary as input in the modeling code, are then prepared from kriging interpolation of this data set at different spatial resolutions.

\subsection{CEA modeling code}

The second step of tsunami modeling has been done using the tsunami calculation code developed by the CEA (Commissariat à l'Energie Atomique, France), adapted from the SWAN (Simulating Waves Nearshore) code of Mader (1988), which solves the shallow water long wave equations, derived from the Navier-Stokes equations. The initial coseismic deformation of the seafloor is still computed through Okada's (1985) elastic dislocation equations and transmitted without loss to the entire water column above. Then tsunami propagation satisfies the following hydrodynamic equations of continuity (1) and motion conservation (2)

$$
\begin{aligned}
& \frac{\partial(\eta+h)}{\partial t}+\nabla \cdot[v(\eta+h)]=0, \\
& \frac{\partial v}{\partial t}+(v \cdot \nabla) \cdot v=-g \nabla \eta,
\end{aligned}
$$

where $\eta$ corresponds to water elevation, $h$ to water depth, $v$ to the horizontal speed vector, while $g$ is the gravity constant.

Nonlinear terms are taken into account, and the resolution is carried out using a Crank-Nicolson finite difference method centered in time and using an upwind scheme in space. This method has been already successfully applied for studies in the Mediterranean Sea, the Pacific and Atlantic Oceans (Hébert et al., 2001; Roger and Hébert, 2008; Roger et al., 2010b). Wave propagation is calculated over 5 levels of nested grids ( 2 levels, grid 1 and 3 have been introduced 
Table 1. Rupture parameters of a 1843 -like $M_{\mathrm{W}}=8.5$ scenario, $M_{0}=6.92 \times 10^{21} \mathrm{Nm}^{-2}$ and for two $M_{\mathrm{W}}=7.0$ scenarios varying the strike angle.

\begin{tabular}{ccccccccccc}
\hline Scenario & $\begin{array}{c}\text { Lon } \\
\left({ }^{\circ}\right)\end{array}$ & $\begin{array}{c}\text { Lat } \\
\left({ }^{\circ}\right)\end{array}$ & $\begin{array}{c}\text { Depth of } \\
\text { fault } \\
\text { center } \\
(\mathrm{km})\end{array}$ & $\begin{array}{c}\text { Slip } \\
(\mathrm{m})\end{array}$ & $\begin{array}{c}\text { Strike } \\
\left({ }^{\circ}\right)\end{array}$ & $\begin{array}{c}\text { Dip } \\
\left({ }^{\circ}\right)\end{array}$ & $\begin{array}{c}\text { Slip } \\
\text { angle } \\
\left({ }^{\circ}\right)\end{array}$ & $\begin{array}{c}\text { Length } \\
(\mathrm{km})\end{array}$ & $\begin{array}{c}\text { Width } \\
(\mathrm{km})\end{array}$ & $\begin{array}{c}\text { Rigidity } \\
\left(\mathrm{Nm}^{-2}\right)\end{array}$ \\
\hline (1) Mw8.5 & -61.17 & 16.73 & 40 & 8.0 & 145 & 25 & 90 & 300 & 100 & $3 \times 10^{10}$ \\
(2) Mw7.0 & -59.04 & 16.0 & 10 & 1.0 & 145 & 25 & 90 & 50 & 25 & $3 \times 10^{10}$ \\
(3) Mw7.0 & -59.04 & 16.0 & 10 & 1.0 & 170 & 25 & 90 & 50 & 25 & $3 \times 10^{10}$ \\
\hline
\end{tabular}
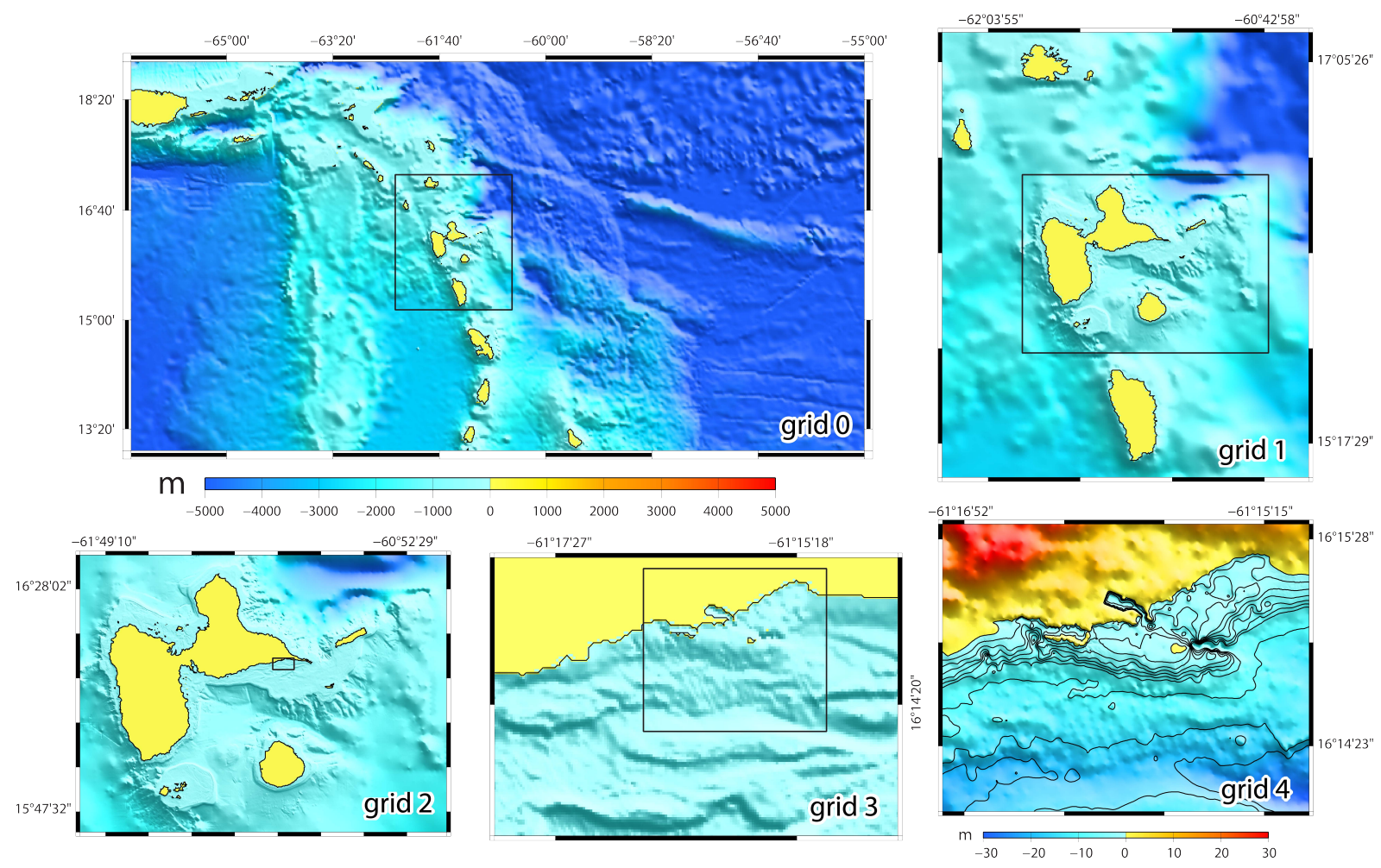

Fig. 4. Digital elevation grids used for numerical modeling from level 0 (resolution 1') to level 4 (resolution $10 \mathrm{~m}$ - the black lines represent isobaths every meter from 0 to $-5 \mathrm{~m}$ and then every $5 \mathrm{~m}$ ) used with the CEA code. Black rectangles symbolize the grid-level below.

for numerical stability) prepared using the same data set constructed for ComMIT preliminary tests (Fig. 4) using a twoway grid-nesting scheme. The first grid (Grid 0 ) has a spatial resolution of $1^{\prime}$ and represents the northern part of the Lesser Antilles Arc. Grid 2 represents the Guadeloupe Archipelago at a resolution of $\sim 150 \mathrm{~m}$. Grid 4 represents the harbor of Saint-François with a resolution of $10 \mathrm{~m}$ reproducing the sea defense structures as docks or piers of the Old Harbor and the Marina. For the purpose of studying the role played by the fringing reef on the tsunami behavior, two other grids of Saint-François and surroundings have been prepared using Grid 4 (Fig. 5a) and showing the same spatial resolution: on the first one, the gap of the fringing reef in front of the Marina has been filled in (Fig. 5b); and on the second one, the reef has been removed (Fig. 5c). The advantage of using this second modeling code is the absolute liberty on the seismic source parameters, in which case, it is easier to chose rupture parameters in good agreement with geologic and geophysics data.

In accordance with the 1843 earthquake epicenter (Lon: $61.17^{\circ} \mathrm{W}$, Lat: $16.73^{\circ} \mathrm{N}$ ) proposed by Feuillard (1985) and with respect to the accurate studies of Bernard and Lambert (1988), who proposed a magnitude $\mathrm{Mw}=7.5-8.0$ offshore rupture of circa $300 \mathrm{~km}$ (with the help of iso-seismal maps), and more recently Feuillet et al. (2011), who demonstrate that this event was probably the expression of a megathrust rupture on the subduction plane, with a magnitude re-evaluated to $\mathrm{Mw}=8.0-8.5$, we propose a tsunami 

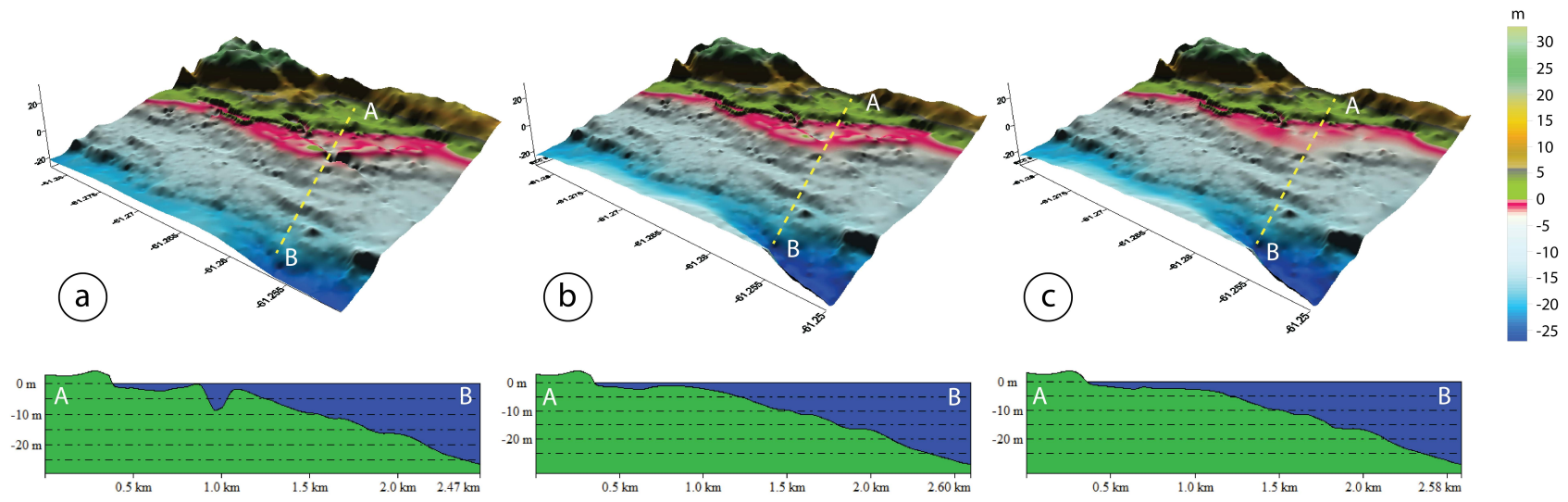

Fig. 5. The 3 different grids of St François: (a) normal bathymetry interpolated from existing data sets; (b) the same grid without a gap within the fringing reef; (c) the same grid without the fringing reef. A bathymetric profile underlines the characteristic of each grid.

generation scenario for a 1843-like event. The empirical relationships between rupture parameters determined by Wells and Coppersmith (1994) indicate that a magnitude $\mathrm{Mw}=8.5$ earthquake corresponds to a rupture surface of about $5 \times 10^{4} \mathrm{~km}^{2}$ leading to a rupture plane width of $\sim 150 \mathrm{~km}$. Recent publications, from Blaser et al. (2010) and Strasser et al. (2010), developed new relationships including subduction zone earthquakes: a $300 \mathrm{~km}$-long rupture seems to correspond to a width of $100 \mathrm{~km}$ for interface ruptures.

The coseismic displacement along the fault plane is estimated using Kanamori's (1977) law, $M_{\mathrm{W}}=\frac{2}{3} \log M_{0}-6.03$, which gives us a seismic moment $M_{0}$ of $6.92 \times 10^{21} \mathrm{~N} \mathrm{~m}^{-1}$ for a $M_{\mathrm{W}}=8.5$ earthquakes, and the relationship from Kanamori and Anderson (1975) between the seismic moment, the shear modulus $\mu$ (rigidity coefficient in $\mathrm{N} \mathrm{m}^{-2}$ ), the rupture surface $S$ (in $\mathrm{m}^{2}$ ) and the coseismic average slip $D$ (in m): $M_{0}=\mu S D$. Using a shear modulus of $30 \mathrm{GPa}$ (i.e., $3 \times 10^{10} \mathrm{~N} \mathrm{~m}^{-2}$ ) with the empirical law proposed by Bilek and Lay (1999), we obtain a coseismic slip of $8.0 \mathrm{~m}$; this value is in quite good agreement with the relationship between surface rupture length and maximum displacement obtained by Wells and Coppersmith (1994). Considering an average compression rate of $2 \mathrm{~cm} / \mathrm{yr}$ and a fully coupled subduction (that is probably not exactly the case for the Lesser Antilles subduction), it corresponds to a strain accumulation on the subduction interface over 400 years.

The strike is copied from the trench azimuth and set to $N$ $145^{\circ} \mathrm{E}$. The rake is consistent with a pure compressive mechanism (reverse faulting). The dip is estimated to $25^{\circ}$ from available depth-related seismicity profiles (Dorel, 1991; Ruiz et al., 2011) and vertical profiles of the regional seismicity from USGS-NEIC (US Geological Survey-National Earthquake Information Center) catalog (from 1973 to present). The epicenter's location vertical profiles of Dorel (1991) have been also used to locate the fault plane with a fault plane center around $35-40 \mathrm{~km}$ depth in this part of the arc, corresponding also to the epicenter depth proposed by Feuillard (1985). According to sensitivity tests done by Okal (1988), the source depth plays a limited role on the tsunami amplitude.

The parameters of this 1843-like scenario are summarized in Table 1. Parameters for two other scenarios of magnitude $\mathrm{Mw}=7.0$, located on the subduction interface (closer to the trench) and added for the sensitivity study showing two different strikes, are also detailed in Table 1 . Those parameters have been determined using the same references of the 1843like scenario and the same empirical laws giving relationships between parameters.

The initial deformation surface computed from Okada's equations, as mentioned earlier in this paper, is shown in Fig. 6 and it is in good agreement with the rupture area proposed by Feuillet et al. (2011). Note that the eastern part of Guadeloupe is located within the positive deformation area (less than $50 \mathrm{~cm}$ ), thus being able to justify the possible elevation of some creeks in this area in 1843, as mentioned by Bernard and Lambert (1988).

\subsection{Modeling results}

\subsubsection{Using ComMIT}

Modeling results obtained using ComMIT software show that a magnitude $\mathrm{Mw}=8.5$ coseismic rupture is able to trigger a catastrophic tsunami of several meters high towards the populated coasts of the Lesser Antilles, and particularly Guadeloupe, which is located very close to the estimated rupture zone (Fig. 7, top panel). In comparison, a 1867 Virgin Islands-like earthquake seems to be able to produce waves below $1 \mathrm{~m}$ high (Fig. 7, bottom panel). In that way, the lack of historical tsunami data for the 1843 event, except for Antigua, should lead to further investigations to determine why so few coeval reports have been found. Apart from that, propagation snapshots on grid B (Fig. 8) highlight a particular behavior of the tsunami when approaching the Guadeloupian promontory. La Désirade, the easternmost point of 


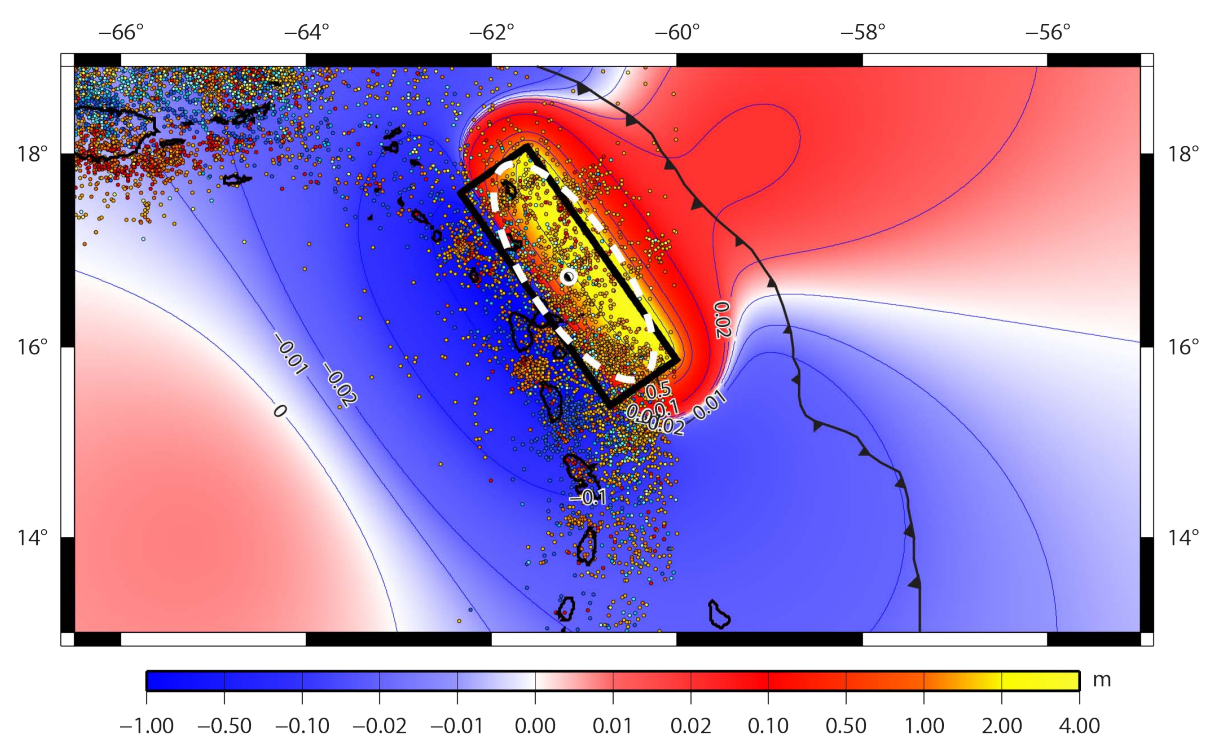

Fig. 6. Initial coseismic deformation of the seafloor computed for a 1843-like event. The black rectangle symbolizes location of the rupture plane superimposed with the rupture area proposed by Feuillet et al. (2011) symbolized with a white dashed ellipse. The subduction trench (black line) and local seismicity from USGS-NEIC (1973 to present) are also indicated.

the archipelago, acts like a shield slowing down the incident waves, leading to the wrapping of those ones around it and focusing the tsunami energy south of this island towards Petite-Terre Islands. This uninhabited nature reserve separates, in turn, the incoming front into two main energy pathways travelling towards the two main touristic towns of the south coast of Grande-Terre: Saint-François and Sainte-Anne (Yellow stars in Fig. 1c). Notice that the area between PetiteTerre and the eastern point of Grande-Terre, called Pointedes-Châteaux, is all the time subject to a resonance phenomenon underlined by wave amplification and strong currents. The comparison with modeling results obtained from the same set of grids for a 1867-like scenario, i.e., with a different geographic location and azimuthal direction than the 1843 event, exhibits amplification in the same coastal points (Fig. 7), without amplitude considerations (not the same earthquake and tsunami magnitudes). As amplifying information, Roger et al. (2010a) identified the same coastal hot spots for tsunami waves coming from the Iberian Peninsula, in the case of a 1755 teletsunami-like event. Considering these propagation snapshots and the maximum wave height maps obtained for the maximum historical scenarios, the area located between la Désirade, Petite-Terre and the easternmost part of Guadeloupe is of major interest. The touristic town of Saint-François (Fig. 2), which seems to be one of the focal points for tsunami waves coming from the east and the north, is located in this triangle and is partially protected from classical waves by a fringing coral reef.

The second part of this study will aim to determine the role played by this fringing reef and the consequences in terms of tsunami hazard assessment.

\subsubsection{Using CEA modeling code}

In order to model tsunami propagation using our own scenarios, with geologically-based parameters, we decided to use the CEA modeling code. Results obtained with this second code are described in the following.

Figure 9 shows maximum wave height maps reached over grids 0 (Lesser Antilles scale) and 2 (Guadeloupe Archipelago) after $1 \mathrm{~h}$ of tsunami propagation for the 1843like event. We can see that those results are in quite good agreement with the results obtained using ComMIT software. The main part of the energy released by the rupture in terms of tsunami propagation and amplitude is concentrated in the direction perpendicular to the fault plane azimuth, as indicated for example by Titov et al. (2005). It also depicts that the source directivity (thrust faulting) sends most of the tsunami energy in the direction perpendicular to the subduction trench, as previously shown by other studies of elongated sources (for example Kowalik et al., 2006; Carrier and Yeh, 2010), and thus, towards the North Atlantic Ocean and the Lesser Antilles islands, with maximum wave heights $(>5 \mathrm{~m})$ recorded in Guadeloupe, but also in Antigua to the north, and in Dominica and Martinique to the south. Only little energy passes through the islands arc. Notice that coastal wave heights are not uniformly distributed and that several coastal points are more prone to wave amplification. For Martinique, the maximum wave heights are located in the funnel-shaped bay of La Trinité (northeast of the island) as previously observed by Roger et al. (2010b) for the 1755 tsunami modelings. Finally, the Lesser Antilles Arc seems to act like a shield, protecting the Caribbean Sea from tsunami triggered at the subduction 


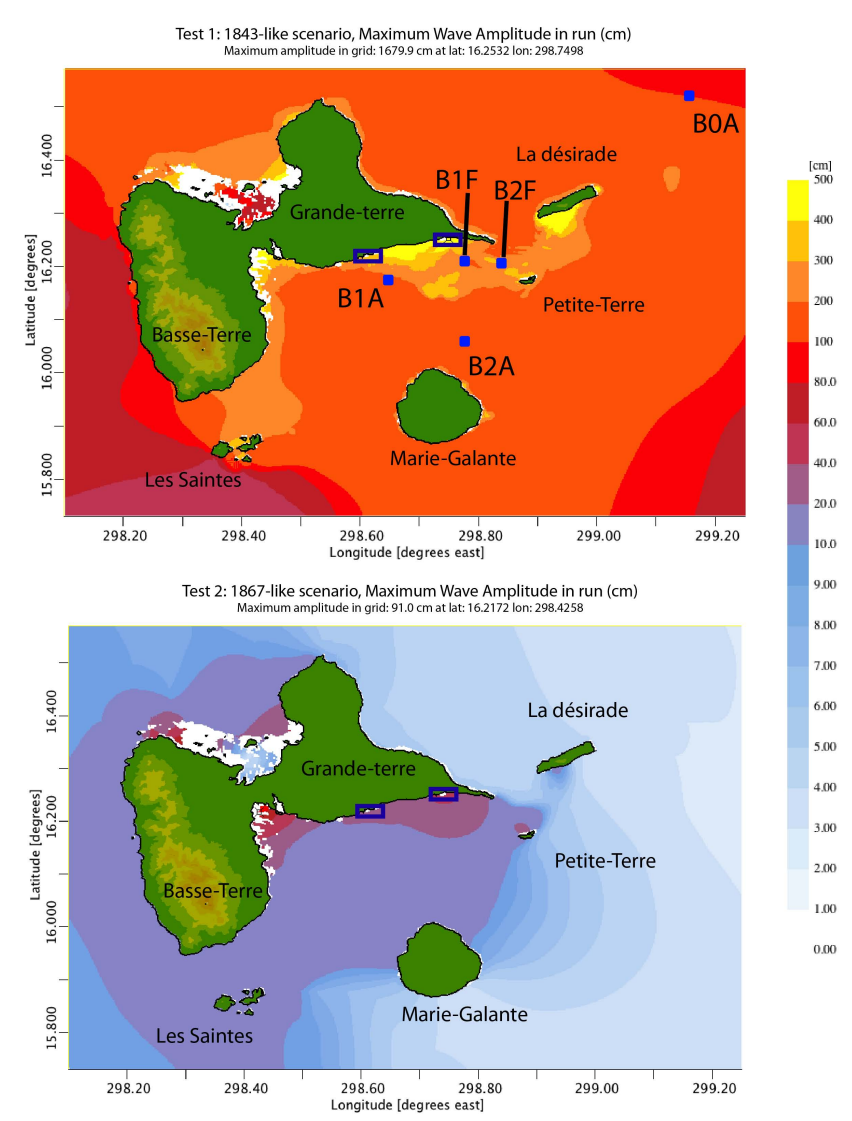

Fig. 7. Maximum wave amplitudes around Guadeloupe obtained with ComMIT software with a 1843-like scenario (Test 1) and a 1867-like scenario (Test 2). Synthetic tide gage locations are represented with blue squares on grid B: B1A, B2A for Sainte-Anne, B1F and B2F for Saint-François; B0A for both sites. Rectangles symbolize Sainte-Anne and Saint-François areas. The color scale is given in centimeters.

zone. The focus on Guadeloupe Archipelago highlights the fact that some places along Guadeloupe coastlines are more sensitive than others to tsunami wave amplification. Indeed, the shallow area between La Désirade, Petite-Terre and the easternmost part of Grande-Terre reacts particularly well to tsunami arrival, showing wave heights of more than $10 \mathrm{~m}$ in the Saint-François locality. Other places like the eastern coast of Grande Terre bays, around Marie-Galante or along the northern part of Basse-Terre, also exhibit wave heights of more than $5 \mathrm{~m}$. The semi-enclosed area between the islands of Les Saintes seems to be subject to a resonance phenomenon as those observed in Hawaii after the 2006 Kuril Islands tsunami (Munger and Cheung, 2008) or in the Marquesas Islands (French Polynesia) after the 2009 Samoa tsunami (Allgeyer et al., 2010).

Focus on Saint-François, using a high resolution DEM, prepared by accurately using bathymetric data from the French Navy and nautical charts, and also street and aerial views of the coastal infrastructures, reveals different areas on the maximum water elevations (MWE) map (Fig. 10) obtained after one hour of tsunami propagation triggered by a 1843-like coseismic rupture: principally the area in front of the Marina and the Old Harbor seems to be more protected than the neighboring areas though located behind the reef. To understand how the tsunami behaves when approaching the coast in Saint-François, we placed 8 tide gages on Grid 4, from offshore to the Marina (Fig. 10a) and the Old Harbor (Fig. 10b), towards the fringing reef. Figure 10a shows that the first arriving wave, highlighted by a progressive sea level rising between 12 and 30 min after the main shock, is amplified from 3 to $4.5 \mathrm{~m}$ when approaching the coast (shoaling effect, gages 6 to 1). On the other hand, the behavior of the second wave is typically related to the presence of the reef. It is preceded by an important sea withdrawal $(>8 \mathrm{~m})$ in front of the reef (gage 5) leading to an emptying of the lagoon (between the reef and the coast), which occurs depending directly on the reef existence and the width of the reef gap in front of the Marina, slowing down the emptying (gages 4, 3 and 1). Then the sea level rises quickly but the presence of the reef slows down the filling of the lagoon (gage 3) and the Marina (gage 1). The behavior is quite similar over the profile from offshore (gage 6) towards the Old Harbor (gage 2), with less amplification of the second leading wave (Fig. 10b). A graphical frequency analysis (spectral density only) of the different signals using Fast-Fourier Transform (FFT), displayed in Fig. 10c, helps to understand the energy transfers between the waves recorded offshore (gage 6) and within the Marina (gage 1). It is clearly visible that the incident wave (gage 6) gains energy when approaching the coast (gage 5) probably because of resonance phenomena acting at several specific frequencies such as the first low-frequency peak at 0.05 . Then energy is lost when travelling through the reef gap and towards the Marina, principally underlined by an absorption of the main low frequency peak. Despite this, a peak reveals a little energy increase from outside to inside the Marina around 0.17 , probably associated with a free oscillation inside the Marina.

The role played by the bathymetry and thus, by the fringing reef, is of major concern within the framework of tsunami hazard assessment. Figure 11 shows maximum water elevation (MWE) maps obtained after one hour of tsunami propagation on 3 different cases of Grid 4: (a) represents the real case, i.e., with a fringing coral reef with a gap; (b) represents the case of a reef without gap; and (c) represents the case of an island shelf without reef. At a first glance, it seems to be quite identical, with minor differences of water depth on land. But the consideration of synthetic tide gages, as the one located at the entrance of the Marina (gage 3), shows major differences in terms of waves withdrawal (Fig. 11d). Indeed, a case with no reef shows a more important decrease in sea level (about $1 \mathrm{~m}$ depth more) than with a normal reef with a gap, and a case with a reef having no gap keeps more water and longer inside the lagoon. The wave amplitude is a bit more important in the case without a reef. 

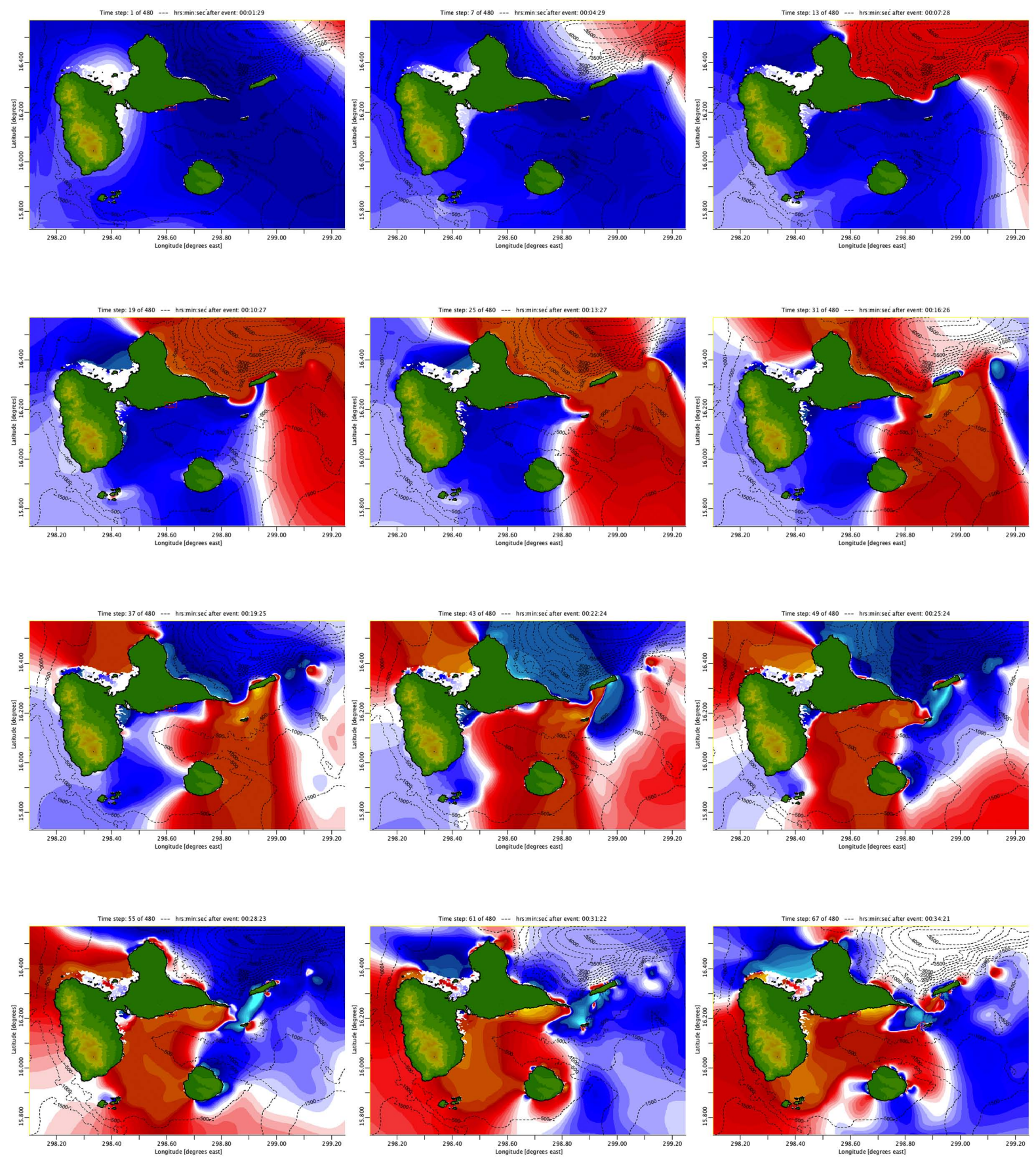

Fig. 8. Tsunami propagation towards the Guadeloupian Archipelago: focus on the main tsunami front wrapping around La Désirade and Petite-Terre Islands and refocusing in two directions.

A magnitude $\mathrm{Mw}=7.0$ source has also been tested to help assess tsunami hazard for a more "common" magnitude in the Lesser Antilles. The parameters have also been determined using geologic and geophysical data (Table 1). Two scenarios are proposed to test the influence of rupture direction (strike angle) and the results are shown in Fig. 12a and $b$. Even if the same areas react again, the wave heights reached by the tsunami in coastal areas are different, ranging from tens of centimeters in one case to twice as high on the other case. The synthetic tide gage located at the entrance of Saint François' Marina (Fig. 12c) highlights this variation on the first leading wave, from $0.27 \mathrm{~m}$ for a $145^{\circ}$ strike angle to $0.43 \mathrm{~m}$ for a maximum energy path oriented toward the Guadeloupe Archipelago (170 ${ }^{\circ}$ strike angle). 


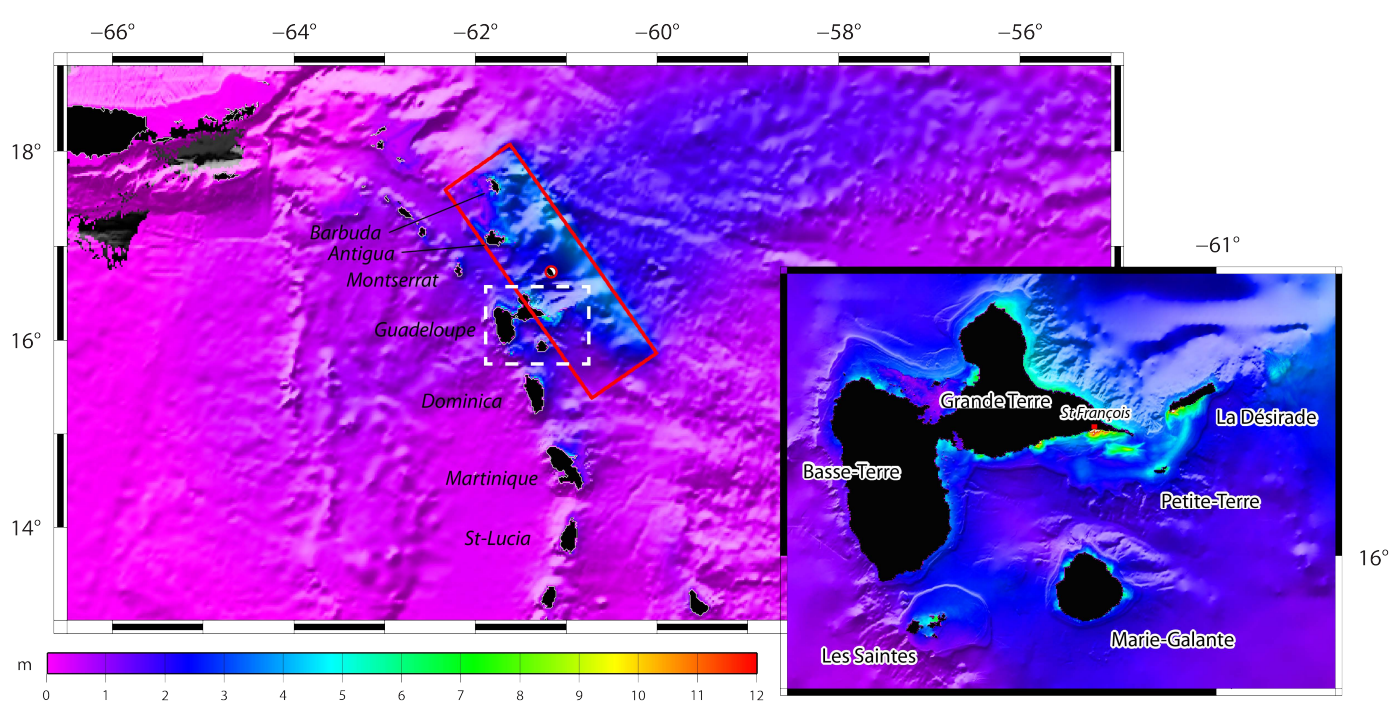

Fig. 9. Maximum wave heights illuminated by a bathymetric gradient obtained for Grid 0 and Grid 2 after one hour of tsunami propagation with the CEA code. The red rectangle symbolizes the fault plane location. The white dashed rectangle locates Grid 2 boundaries on Grid 0 .

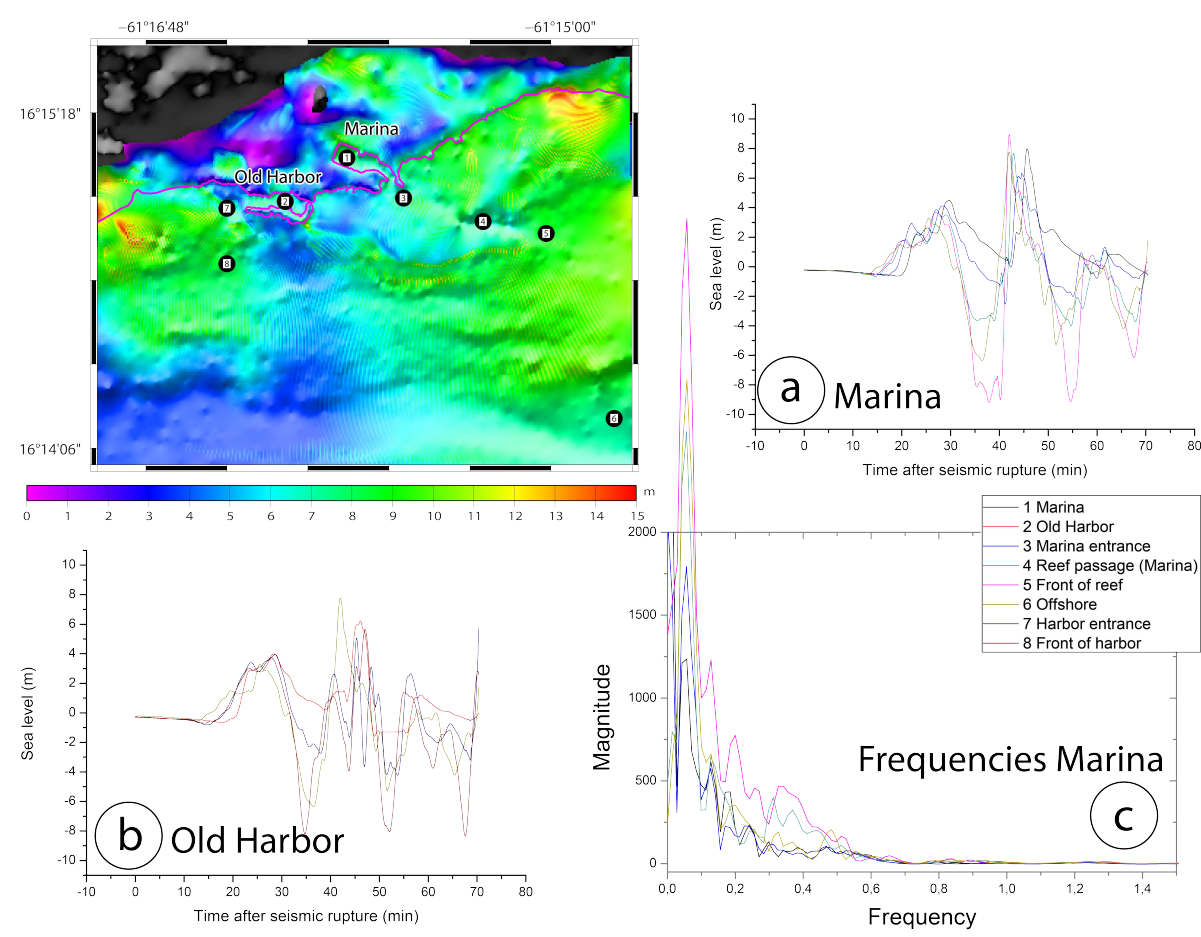

Fig. 10. Maximum water depths illuminated by a bathymetric gradient and inundation limit obtained on Grid 4 (Saint-François) after one hour of tsunami propagation. The color scale is different from Fig. 9. Eight synthetic tide gages have been located on this grid and symbolized with numbers within a black circle. Synthetic gage records are shown in (a) for the Marina profile and (b) for the Old Harbor profile. (c) Represents the frequency analysis of the gage records for the Marina profile.

\section{Discussion}

The results obtained using different source locations (Virgin Islands source, 1843-like source), two different magnitude earthquakes ( $\mathrm{Mw}=7.0$ and 8.5) located on the subduction interface and those using two different strikes, show that it is necessary to be very cautious when determining the rupture parameters, as the variation of one of them could have considerably influenced the final results. The role of strike angle has been previously discussed by Roger and Hébert (2008) concerning the impact of Algerian tsunamis in the western 

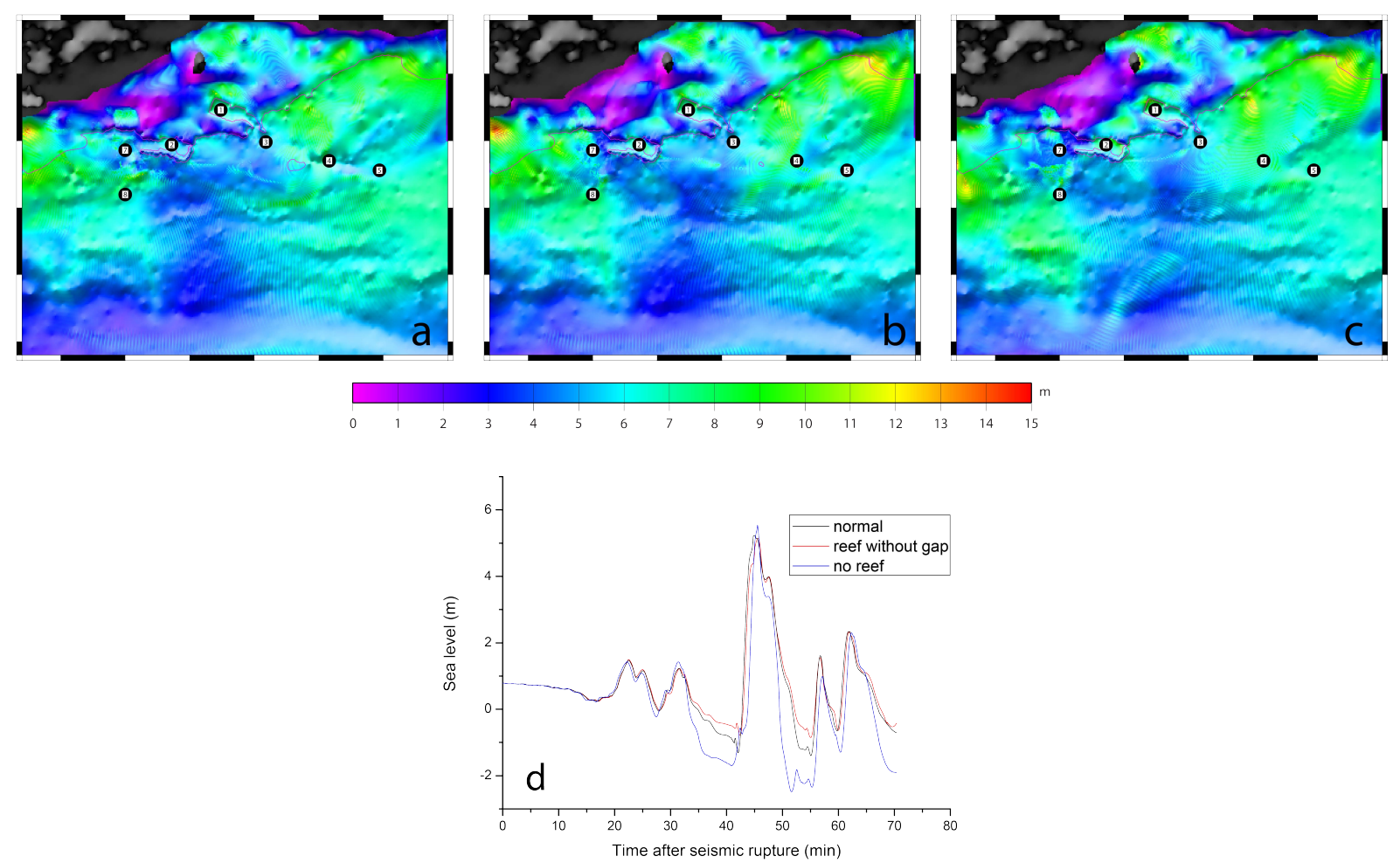

Fig. 11. Maximum water depths illuminated by a bathymetric gradient and inundation limit obtained on 3 different cases of Grid 4 (SaintFrançois) after one hour of tsunami propagation: (a) normal case; (b) reef without gap in front of the Marina; (c) no reef in front of the Marina. (d) Presents the synthetic tide gage records at the Marina entrance in the 3 cases.

Mediterranean, or by Barkan et al. (2009) and their modelings of the 1755 Lisbon tsunami in the North Atlantic Ocean. More generally, knowledge of the focal mechanisms of the seismic rupture, including rake angle and slip value determination, will help to propose the best scenario able to reproduce as well as possible tsunami generation by earthquakes as demonstrated, for example, by Geist (1998), Geist and Dmowska (1999) or Okal and Synolakis (2004). Thus, an accurate study (for tsunami warning purposes for example) would encompass both azimuthal coverage of the potential sources around the considered region and a range of strike angles for each fault plane ("security" range).

In the case of near-field tsunami generation offshore Guadeloupe upon the subduction interface, it takes only between $10(\mathrm{Mw}=8.5)$ and $15 \mathrm{~min}(\mathrm{Mw}=7.0)$ for the first leading wave (delay depending mainly on the location of the top of the rupture zone, its width and dip: the closer it is from the trench, the farther is the first leading wave from the islands) to reach the south coast of Grande-Terre, after wrapping around La Désirade and Petite-Terre Islands. Concerning its northeastern coast, directly exposed to oceanic swells and thus to tsunami threat, the arrival time is less than $10 \mathrm{~min}$ after the mainshock, i.e., nothing in terms of tsunami warning and evacuation.
As amplifying information, Dao and Tkalich (2007) indicate that the friction parameter (Manning's roughness), not considered in the present modeling, does not play a significant role on tsunami wave arrival time. Friction could only have influence on the wave amplitude as discussed by several authors as Kunkel et al. (2006) or Fernando et al. (2008). Anyway, in the case of estimating tsunami hazard for coastal communities, not introducing a friction coefficient in our calculations (in shallow waters and on land), leading to a possible overestimation of the coastal maximum wave heights and the inundation limits (Geist, 1998) is not a problem, in one hand, as long as we do not use a highly accurate DEM (i.e., around $1 \mathrm{~m}$ resolution) perfectly reproducing the fringing coral reef and all the topographic features, including buildings and sea defenses; and on the other hand, because we do not compute wave breaking able to lead to an important dissipation of energy (depending on the slope angle) ( $\mathrm{Li}$ and Raichlen, 2002).

Wave amplification due to resonance phenomena is probably more important to consider especially within (semi-) enclosed shallow water bodies like lagoons or harbors. Indeed, the detailed frequency analysis, presented in Fig. 12e for a set of tide gages located on the two paths (Fig. 7) resulting from the wrapping of the tsunami around PetiteTerre (Fig. 8), highlights some resonance amplifications of 

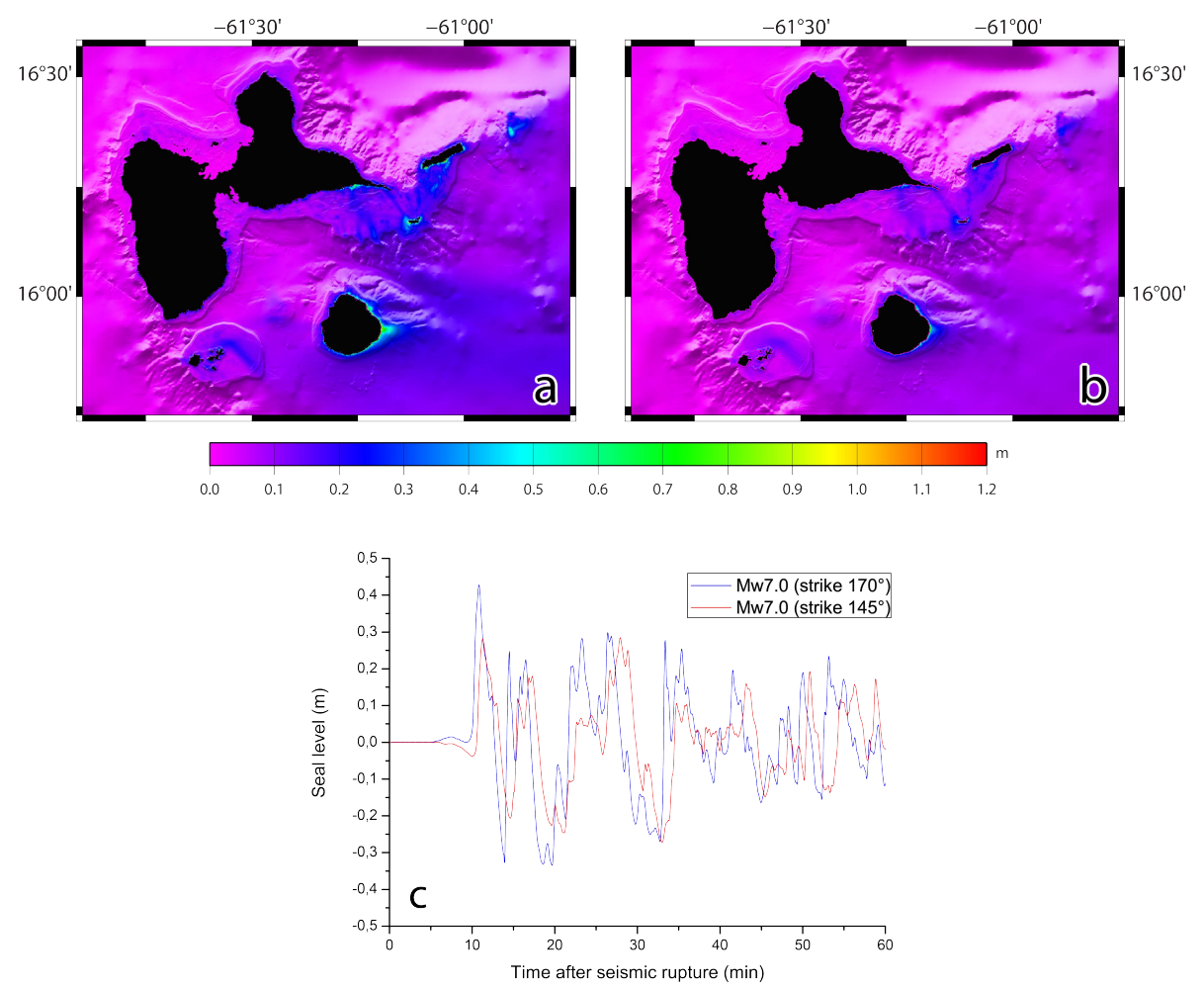

Fig. 12. (a) Maximum wave heights illuminated by a bathymetric gradient obtained for Grid 2 after one hour of tsunami propagation triggered by a magnitude $\mathrm{Mw}=7.0$ earthquake varying the strike angle of the coseismic rupture plan. It corresponds to a strike angle of (a) $170^{\circ}$ and (b) $145^{\circ}$. Synthetic tide gage records at the Marina entrance in both cases are presented in (c).

the tsunami signal travelling from offshore La Désirade to the coastal towns of Sainte-Anne and Saint-François. The signal has been recorded on several synthetic tide gages positioned along the tsunami path (located on Fig. 7); it includes two tide gages positioned in and off Sainte-Anne's lagoon (C1A and C2A) and in and off Saint-François' lagoon (C1F and $\mathrm{C} 2 \mathrm{~F}$ ) (located on Fig. 2). The FFT of the recorded signals, using a Hanning window, shows the apparition, amplitude evolution and/or disappearing of frequency peaks (Fig. 12e) due to coastal trapped oscillations and basin resonances. The first peaks $\mathrm{P} 1 \approx 4000 \mathrm{~s}-66 \mathrm{~min}-(0.00025 \mathrm{~Hz})$ and $\mathrm{P} 2 \approx 1600 \mathrm{~s}-26 \mathrm{~min}-(0.0006 \mathrm{~Hz})$ are directly linked to the geometry of the source (the coseismic seafloor deformation generates a wave with a particular frequency spectrum; this frequency content will be highlighted with the dispersion phenomenon during tsunami propagation in deep water). A global loss of energy between $\mathrm{C} 2 \mathrm{~F}$ and $\mathrm{C} 1 \mathrm{~F}$ is obvious on the frequency spectra, indicating a possible dissipation of energy due to the reef; nevertheless, a peak appears (P4) corresponding probably to coastal trapped waves amplification, as explained by Munger and Cheung (2008). An amplification on Sainte-Anne's tide gages is revealed with the apparition and amplification of new frequency peaks (P2 or P3) and signal phase variation between $\mathrm{C} 2 \mathrm{~A}$ and $\mathrm{C} 1 \mathrm{~A}$. This is probably linked to a resonance within the gaps of the reef barrier, or inside the semi-enclosed bay because of similarities between incoming wave eigenperiods and natural eigenperiods of the bay (previously determined by Roger et al., 2010a).

According to these results, fringing reefs seem to play a predominant role on the incident wave amplitude and frequency content. Nevertheless, this role is controversial according to previous studies: some of them show that the effects of reefs are either principally positive, i.e., they are able to reduce tsunami impact (Nott, 1997; Kunkel et al., 2006; Baba et al., 2008; Mohandie and Teng, 2011) or more negative, increasing the coastal impact (Lynett, 2007; Roeber et al., 2010). For example, after the 2004 Indonesian tsunami, Kunkel et al. (2006) simulate tsunami propagation over a reef and show that the run-up over an idealized topography located behind the reef is directly linked to the reef width; but they are cautious with the results' interpretation, underlining also the dependence of the run-up with the incident wavelength and amplitude as well as the geometry and health of the reef (dissipating energy through bottom friction). In addition, Gelfenbaum et al. (2011) indicate that the greatest protection from destructive tsunamis will come from wide and high rough coral reefs, showing as little gaps as possible. Roger et al. (2013) analyzes in depth, using a set of artificial DEMs of a fringing reef facing a sloping beach to evaluate 

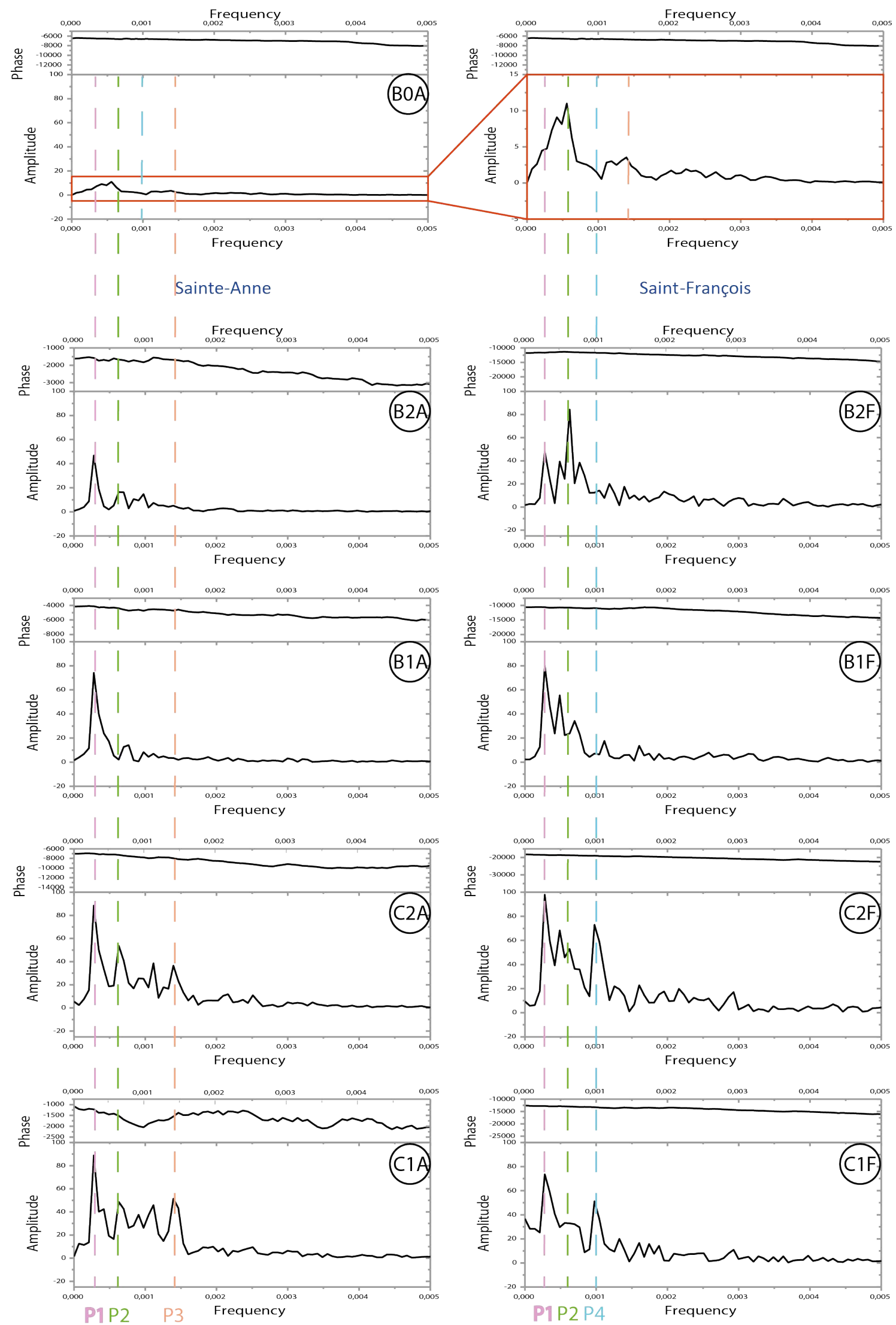

Fig. 12. (e) Frequency analysis of synthetic tide gage signals located on the tsunami path from the source area towards Sainte-Anne (left column) and Saint-François (right column). Main frequency peaks are indicated by P1, P2, P3 and P4. 
the role of each parameter of the reef such as width, depth, etc.

\section{Conclusions}

Aided with numerical modeling and largely referring to historical tsunami catalogs, this study shows firstly that the coasts of the Guadeloupe Archipelago are able to react to tsunami wave arrivals. This reaction is resulting into tsunami wave amplification in specific coastal places due to wave shoaling and resonance phenomena whatever the source location, the rupture azimuth, and finally, the earthquake magnitude. Wave refocusing behind La Désirade and then PetiteTerre, leading to two main tsunami paths and important maximum wave heights in Sainte-Anne and Saint-François localities, indicates that this phenomenon should be taken into consideration for tsunami hazard mitigation, as well as the role played by resonance in front of these two touristic coastal places. Resonance inside the bay of Sainte-Anne revealed by frequency analysis could explain the unique observation of the 1755 tsunami inundation in this site, as previously indicated by Roger et al. (2010a).

Through the analysis of synthetic tide gage records, this study also highlights the fact that the relative protection of the coast is partially related to the existence and shape of the fringing coral reef.

Results obtained using the CEA modeling code match those obtained with ComMIT software in terms of wave propagation style around the islands and coastal amplification. Despite the limitation of the second one, considering the source location as well as the source parameters choice, ComMIT is quite a good, easy-to-use tool for producing quickly preliminary maximum wave heights and inundation maps for emergency response.

Despite the low tide amplitudes in these parts of the Caribbean (Kjerfve, 1981), it would probably be very interesting to model and compare the tsunami propagation over the coral reefs at high tide. This would lead to a comparison of the results obtained considering the occurrence of a storm surge during the tsunami arrival, the case of a multihazard scenario, elevating the mean sea level several tens of centimeters to several meters; as further information, during hurricane Hugo (17 September 1989) the maximum surge elevation in Guadeloupe reached $2.5 \mathrm{~m}$ recorded at BaieMahault's tide gage station.

Modeling results of a 1843-like megathrust event underline another major issues concerning the lack of historical coeval reports of tsunami waves on 8 February 1843 in the Guadeloupe Archipelago: Why are there no descriptions of important tsunami waves at least in Le Moule, the most important sea trade place in Guadeloupe until circa 1850, after what it stopped to thrive? The only observation of oscillations of several tens of centimeters reported in Pointe-à-Pitre, a town located at the far end of a bay, itself protected by a wide shelf behind a fringing reef, should be related to substantial tsunami waves along the eastern and southern coast of Grande-Terre. A deepened search of historical data associated to a better understanding of the rupture conditions linked to the subduction processes of the Lesser Antilles zone should be lead to fill in this comprehensive gap.

This study also highlights the necessity to protect the fringing coral reefs of Guadeloupe as a natural means of protection against potential tsunami waves.

Acknowledgements. This work has been funded by the European INTERREG IV TSUNAHOULE project managed by the Laboratoire de Recherche en Géosciences et Energies (University of the Antilles and French Guyana). We are also very grateful to the Editor Stefano Tinti and to José A. Alvarez-Gomez and an anonymous referee for their constructive comments helping to improve the manuscript.

Edited by: S. Tinti

Reviewed by: J. A. Alvarez and another anonymous referee

\section{References}

Allgeyer, S., Hébert, H., and Madariaga, R.: Modelisation of the impact of tsunamis and free oscillation in French Polynesia, Geophys. Res. Abstr., 12, EGU2010-9435-1, 2010.

Baba, T., Mleczko, R., Burbidge, D., Cummins, P. R., and Thio, H. K.: The effect of the Great Barrier Reef on the propagation of the 2007 Solomon Islands tsunami recorded in Northeastern Australia, Pure Appl. Geophys., 165, 2003-2018, 2008.

Barkan, R., Ten Brin, U., and Lin, J.: Far field tsunami simulations of the 1755 Lisbon earthquake: implications for tsunami hazard to the U.S. East Coast and the Caribbean, Mar. Geol., 264, 109122, 2009.

Bernard, P. and Lambert, J.: Subduction and seismic hazard in the Northern Lesser Antilles: revision of the historical seismicity, B. Seismol. Soc. Am., 78, 1965-1983, 1988.

Bilek, S. L. and Lay, T.: Rigidity variations with depth along interplate megathrust faults in subduction zones, Nature, 400, 443446, 1999.

Blanc, P.-L.: The Atlantic tsunami on November 1st, 1755: world range and amplitude according to primary documentary sources, The tsunami threat - Research and Technology, InTech, 423446, 2011.

Blaser, L., Krüger, F., Ohrnberger, M., and Scherbaum, F.: Scaling relations of earthquake source parameters estimates with special focus on subduction environment, B. Seismol. Soc. Am., 100, 2914-2926, 2010.

Bouchon, C., Portillo, P., Bouchon-Navaro, Y., Max, L., Hoetjes, P., Braithwaite, A., Roach, R., Oxenford, H., O'Farrel, S., and Day, O.: Status of the coral reefs of the Lesser Antilles after the 2005 bleaching event, in: Status of Caribbean Coral Reefs after Bleaching and Hurricanes in 2005, edited by: Wilkinson, C. and Souter, D., Global Coral Reef Monitoring Network, and Reef and Rainforest Research Centre, Townsville, 152 pp., 2008a. 
Bouchon, C., Portillo, P., Bouchon-Navaro, Y., Louis, M., Hoetjes, P., de Meyer, K., Macrae, D., Armstrong, H., Datadin, V., Hardin, S., Mallela, J., Parkinson, R., Van Bochove, J.-W., Wynne, S., Lirman, D., Herlan, J., Baker, A., Collado, L., Nimrod, S., Mitchell, J., Morrall, C., and Isaac, C.: Status of coral reefs of the Lesser Antilles: The French West Indies, The Netherlands Antilles, Anguilla, Antigua, Grenada, Trinidad and Tobago, in: Status of coral reefs of the world: 2008, edited by: Wilkinson, C., Global Coral Reef Monitoring Network and Reef and Rainforest Research Center, Townsville, 265-279, 2008b.

Burke, L., Reytar, K., Spalding, M., and Perry, A.: Reefs at risk revisited, http://www.wri.org/publication/reefs-at-risk-revisited, last access: February 2013, World Resources Institute, 130 pp., 2011.

Carrier, G. F. and Yeh, H.: Tsunami propagation, directivity, and pulse persistence from a finite source, in: Proceedings of the Conference on Water Waves - Theory and Experiment: Howard University, USA, 13-18 May 2008 World Scientific Publishing Company Incorporated, p. 120, 2010.

Clark, J. R.: Coastal zone management, Land Use Policy, 8, 324330, 1991.

Dao, M. H. and Tkalich, P.: Tsunami propagation modelling a sensitivity study, Nat. Hazards Earth Syst. Sci., 7, 741-754, doi:10.5194/nhess-7-741-2007, 2007.

DeMets, C., Mattioli, G., Jansma, P., Rogers, R. D., and Tenorio, C.: Present motion and deformation of the Caribbean plate: constraints from new GPS geodetic measurements, from Honduras and Nicaragua, in: Geologic and Tectonic Development of the Caribbean Plate in Northern Central America, edited by: Mann, P., Special Paper, Geol. Soc. Am., 428, 21-36, doi:10.1130/2007.2428(02), 2007.

Dorel, J.: Seismicity and seismic gap in the Lesser Antilles arc and earthquake hazard in Guadeloupe, Geophys. J. R. Astr. Soc., 67, 679-695, 1991.

Fernando, H. J. S., Samarawickrama, S. P., Balasubramanian, S., Hettiarachchi, S. S. L., and Voropayev, S.: Effects of porous barriers such as coral reefs on coastal wave propagation, J. HydroEnviron. Res., 1, 187-194, 2008.

Feuillard, M.: Macrosismicité de la Guadeloupe et de la Martinique, Institut de Physique du Globe de Paris, Paris, 348 pp., 1985.

Feuillet, N., Manighetti, I., Tapponnier, P., and Jacques, E.: Arc parallel extension and localization of volcanic complexes in Guadeloupe, Lesser Antilles, J. Geophys. Res., 107, 2331, doi:10.1029/2001JB000308, 2002.

Feuillet, N., Beauducel, F., and Tapponnier, P.: Tectonic context of moderate to large historical earthquakes in the Lesser Antilles and mechanical coupling with volcanoes, J. Geophys. Res., 116, B10308, doi:10.1029/2011JB008443, 2011.

Frihy, O. E., El Ganaini, M. A., El Sayed, W. R., and Iskander, M. M.: The role of fringing coral reef in beach protection of Hurghada, Gulf of Suez, Red Sea of Egypt, Ecol. Eng., 22, 1725, 2004.

Geist, E.: Local tsunamis and earthquake source parameters, Adv. Geophys., 39, 117-209, 1998.

Geist, E. and Dmowska, R.: Local tsunamis and distributed slip at the source, Pure Appl. Geophys., 154, 485-512, 1999.

Gelfenbaum, G., Apotsos, A., Stevens, A. W., and Jaffe, B.: Effects of fringing reefs on tsunami inundation: American Samoa, EarthSci. Rev., 107, 12-22, 2011.
Gusiakov, V. K.: Static displacement on the surface of an elastic space, Ill-posed problems of mathematical physics and interpretation of geophysical data, VC SOAN SSSR, Novosibirsk, 23$51,1978$.

Hébert, H., Heinrich, P., Schindelé, F., and Piatanesi, A.: Far-field simulation of tsunami propagation in the Pacific Ocean: impact on the Marquesas Islands (French Polynesia), J. Geophys. Res., 106, 9161-9177, 2001.

Kanamori, H.: The energy release in great earthquakes, J. Geophys. Res., 82, 2981-2987, 1977.

Kanamori, H. and Anderson, D.: Theoretical basis of some empirical relations in seismology, B. Seismol. Soc. Am., 65, 10731096, 1975.

Kjerfve, B.: Tides of the Caribbean Sea, J. Geophys. Res., 86, 4243 4247, 1981.

Kowalik, Z., Knight, W., Logan, T., and Whitmore, P.: The tsunami of 26 December, 2004: numerical modeling and energy considerations, Pure Appl. Geophys., 164, 1-15, 2006.

Kunkel, C. M., Hallberg, R. W., and Oppenheimer, M.: Coral reefs reduce tsunami impact in model simulations, Geophys. Res. Lett., 33, L23612, doi:10.1029/2006GL027892, 2006.

Le Friant, A., Heinrich, P., and Boudon, G.: Field survey and numerical simulation of the 21 November 2004 tsunami at Les Saintes (Lesser Antilles), Geophys. Res. Lett., 35, L12308, doi:10.1029/2008GL034051, 2008.

Li, Y. and Raichlen, F.: Non-breaking and breaking solitary wave run-up, J. Fluid Mech., 456, 295-318, 2002.

Liu, H. and Ghidaoui, M. S.: Investigations of the effects of coral reefs on coastal wave propagation by model simulations, Proceedings of the 33rd IAHR Congress - Water Engineering for a Sustainable Environment, 9-14 August, Vancouver, Canada, 2009.

Lynett, P. J.: Effect of a shallow water obstruction on long wave runup and overland flow velocity, J. Waterway. Port Coast. Ocean Eng., 133, 455-462, 2007.

Mader, C. L.: Numerical modeling of water waves, University of California Press, Berleley, 1988.

Mohandie, R. and Teng, M. H.: Numerical and experimental study on reducing long wave run-up by beach vegetation, Proceedings of the Twenty-first International Offshore and Polar Engineering Conference, 19-24 June, Maui, Hawaii, USA, 2011.

Munger, S. and Cheung, K. F.: Resonance in Hawaii waters from the 2006 Kuril Islands tsunami, Geophys. Res. Lett., 35, L07605, doi:10.1029/2007GL032843, 2008.

Nikolkina, I., Zahibo, N., and Pelinovsky, E.: Tsunami in Guadeloupe (Caribbean Sea), Open Oceanogr. J., 4, 44-49, 2010.

Nott, J.: Extremely high-energy wave deposits inside the Great Barrier Reef, Australia: determining the cause - tsunami or tropical cyclone, Mar. Geol., 141, 193-207, 1997.

O'Loughlin, K. F. and Lander, J. F.: Caribbean tsunamis: A 500year history from 1498-1998, Kluwer Academic Publishers, Dordrecht, The Netherlands, 267 pp., 2003.

Okada, Y.: Surface deformation due to shear and tensile faults in a half-space, B. Seismol. Soc. Am., 75, 1135-1154, 1985.

Okal, E. A.: Seismic parameters controlling far-field tsunami amplitudes: a review, Nat. Hazards, 1, 67-96, 1988.

Okal, E. A. and Synolakis, C. E.: Source discriminants for near-field tsunamis, Geophys. J. Int., 158, 899-912, 2004. 
Pelinovsky, E., Zahibo N., Dunkley, P., Edmonds, M., Herd, R., Talipova, T., Kozelkov, A., and Nikolkina, I.: Tsunami generated by the volcano eruption on July 12-13 2003 at Montserrat, Lesser Antilles, Sci. Tsunami Hazards, 22, 44-57, 2004.

Roeber, V., Yamazaki, Y., and Cheung, K. F.: resonance and impact of the 2009 Samoa tsunami around Tutuila, American Samoa, Geophys. Res. Lett., 37, L21604, doi:10.1029/2010GL044419, 2010.

Roger, J. and Hébert, H.: The 1856 Djijelli (Algeria) earthquake and tsunami: source parameters and implications for tsunami hazard in the Balearic Islands, Nat. Hazards Earth Syst. Sci., 8, 721-731, doi:10.5194/nhess-8-721-2008, 2008.

Roger, J., Allgeyer, S., Hébert, H., Baptista, M. A., Loevenbruck, A., and Schindelé, F.: The 1755 Lisbon tsunami in Guadeloupe Archipelago: source sensitivity and investigation of resonance effects, Open Oceanogr. J., 4, 58-70, 2010a.

Roger, J., Baptista, M. A., Sahal, A., Allgeyer, S., and Hébert, H.: The transoceanic 1755 Lisbon tsunami in the Martinique, Proceedings of the International Tsunami Symposium, Novosibirsk, Russia, July 2009, Pure Appl. Geophys., 168, 1015-1031, 2010 b.

Roger, J., Dudon, B., Krien, Y., and Zahibo, N.: Discussion about tsunami interaction with fringing coral reef, in: Tsunami events and lessons learned; Ecological and societal significance, edited by: Santiago-Fandino, V. and Kontar, Y., Springer, in press, 2013.

Ruiz, M., Galve, A., Monfret, T., Sapin, M., Charvis, P., Laigle, M., Evain, M., Hirn, A., Flueh, E., Gallart, J., Diaz, J., Lebrun, J. F., and the Lesser Antilles Thales scientific party: Seismic activity offshore Martinique and Dominica islands (Central Lesser Antilles subduction zone) from temporary onshore and offshore seismic networks, Tectonophysics, doi:10.1016/j.tecto.2011.08.006, in press, 2011.

SHOM - Service Hydrographique et Océanographique de la Marine: Guadeloupe, De Montserrat à Marie-galante, Echelle $1: 149$ 000, no. 7345, SHOM, Brest, 1994.

SHOM - Service Hydrographique et Océanographique de la Marine: Guadeloupe, Ports et mouillages de Grande-Terre, de Marie-Galante et de la Désirade, Echelle 1:10000, no. 7102, SHOM, Brest, 2008.

Smith, A. F., Rogers, C. S., and Bouchon, C.: Status of Western Atlantic coral reefs in the Lesser Antilles, Proceedings of the 8th Int. Coral Reef Sym., 1, 351-356, 1997.
Strasser, F. O., Arango, M. C., and Bommer, J. J.: Scaling of the source dimensions of interface and intraslab subduction-zone earthquakes with moment magnitude, Seismol. Res. Lett., 81, 941-950, 2010.

Titov, V. V. and Gonzalez, F. I.: Implementation and testing of the Method Of Splitting Tsunami (MOST), NOAA Technical Memorandum ERL PMEL-112, contribution 1927, NOAA/Pacific Marine Environmental Laboratory, Seattle, WA, 14 pp., 1997.

Titov, V. V. and Synolakis, C. E.: Modeling of breaking and nonbreaking long wave evolution and runup using VTCS-2, J. Waterway. Ports Coast. Ocean Eng., 121, 308-316, 1995.

Titov, V. V., Rabinovich, A. B., Mofjeld, H. O., Thomson, R. E., and Gonzalez, F. I.: The global reach of the 26 December 2004 Sumatra Tsunami, Science, 309, 2045-2048, 2005.

Titov, V. V., Moore, C. W., Greenslade, D. J. M., Pattiaratchi, C., Badal, R., Synolakis, C. E., and Kanoglu, U.: A new tool for inundation modeling: Community Model Interface for Tsunamis (ComMIT), Pure Appl. Geophys., 168, 2121-2131, 2011.

Trofimovs, J., Foster, C., Sparks, R. S. J., Loughlin, S., Le Friant, A., Deplus, C., Porritt, L., Christopher, T., Luckett, R., Talling, P. J., Palmer, M. R., and Le Bas, T.: Submarine pyroclastic deposits formed during the 20th May 2006 dome collapse of the Soufrière Hills Volcano, Montserrat, Bull. Volcanol., 74, 391-405, 2011.

Wells, D. L. and Coppersmith, K. J.: New empirical relationships among magnitude, rupture length, rupture width, rupture area, and surface displacement, B. Seismol. Soc. Am., 84, 974-1002, 1994.

Wilkinson, C. R.: Global and local threats to coral reef functioning and existence: review and predictions, Mar. Freshwater Res., 50, 867-878, 1999.

Zahibo, N., Pelinovsky, E., Yalciner, A. C., Kurkin, A., Koselkov, A., and Zaitsev, A.: The 1867 Virgin Island Tsunami, Nat. Hazards Earth Syst. Sci., 3, 367-376, doi:10.5194/nhess-3-3672003, 2003.

Zahibo, N., Pelinovsky, E., Yalciner, A., Zaitsev, A., Talipova, T., Nikolkina, I., and Chernov, A.: Trans-Atlantic propagation of 1755 tsunami and its effects on the French West Indies, Open Oceanogr. J., 5, 30-41, 2011. 